\title{
The Consequences of Landscape Change on Ecological Resources: An Assessment of the United States Mid-Atlantic Region, 1973-1993
}

\author{
K. Bruce Jones, ${ }^{1}$ Anne C. Neale, ${ }^{1}$ Timothy G. Wade, ${ }^{2}$ James D. Wickham, ${ }^{2}$ \\ Chad L. Cross, ${ }^{1}$ Curtis M. Edmonds, ${ }^{1}$ Thomas R. Loveland, ${ }^{3}$ Maliha S. Nash, ${ }^{1}$ \\ Kurt H. Riitters, ${ }^{4}$ and Elizabeth R. Smith ${ }^{2}$ \\ 1 U.S. Environmental Protection Agency, Las Vegas, Nevada; 2 U.S. Environmental Protection \\ Agency, Research Triangle Park, North Carolina; ${ }^{3}$ U.S. Geological Survey, EROS Data Center, \\ Sioux Falls, South Dakota; ${ }^{4}$ U.S. Forest Service, Research Triangle Park, North Carolina
}

\begin{abstract}
Spatially explicit identification of changes in ecological conditions over large areas is key to targeting and prioritizing areas for environmental protection and restoration by managers at watershed, basin, and regional scales. A critical limitation to this point has been the development of methods to conduct such broad-scale assessments. Field-based methods have proven to be too costly and too inconsistent in their application to make estimates of ecological conditions over large areas. New spatial data derived from satellite imagery and other sources, the development of statistical models relating landscape composition and pattern to ecological endpoints, and geo-

graphic information systems (GIS) make it possible to evaluate ecological conditions at multiple scales over broad geographic regions. In this study, we demonstrate the application of spatially distributed models for bird habitat quality and nitrogen yield to streams to assess the consequences of landcover change across the midAtlantic region between the 1970s and 1990s. Moreover, we present a way to evaluate spatial concordance between models related to different environmental endpoints. Results of this study should help environmental managers in the mid-Atlantic region target those areas in need of conservation and protection.
\end{abstract}

\section{INTRODUCTION}

The shrinking and fragmentation of intact, natural landcover have become major environmental concerns worldwide (Turner et al. 1990; Groom \& Schumaker 1993; Houghton 1994; Imhoff 1994; Ojima et al. 1994). Cumulatively, these changes have decreased biological diversity, biotic potential, and the quality of water resources over a variety of scales (Schlesinger et al. 1990; Lubchenco $e t$ al. 1991; UNEP 1992; Woodley et al. 1993; Noss \&

Address correspondence to: K. Bruce Jones, U.S. EPA, P.O. Box 93478, Las Vegas, NV 89193-3478, USA; E-mail jones. bruce@epa.gov.
Cooperrider 1994; Houghton 1994; Ojima et al. 1994; Noss et al. 1995; Saunders et al. 1991). Fragmentation and simplification of natural habitats are primary factors influencing the decline of biological diversity at regional and continental scales (Turner 1989; Turner et al. 1991; Saunders et al. 1991), as is conversion of natural landcover to anthropogenic landcover (Noss et al. 1995). Fragmentation results in decreased sizes of continuous habitat (e.g., interior forests) and decreased connectivity among metapopulations (Verboom et al. 1991). As distances between patches of suitable habitat increase, the probability of extinction increases for individual populations, and the probability of recolonization by surviving popula- 
tions decreases (Verboom et al. 1991). The result of habitat loss and fragmentation is the loss of populations and species over time (Kattan et al. 1994; Koopowitz et al. 1994; Short \& Turner 1994; Knick \& Rotenberry 1995).

Conversion of natural landcover to anthropogenic landcover has had negative consequences on processes of water interception, infiltration, and runoff that determine the magnitude of flooding, water storage, and the quality of drinking water (Peterjohn \& Correll 1984; Saunders et al. 1991; Franklin 1992). Transformation of natural landcover to anthropogenic landcover also increases nutrient loadings to streams and estuaries (Jones et al. 2001).

A primary aim of landscape assessments has been to create indices and models that integrate aspects of landscape condition or health (e.g., see Wickham et al. 1999). Rapport et al. (1998) summarized various aspects of landscape health and concluded that landscape health relates to human values and expectations of aspects of the environment, including certain ecological goods (clean water) and services (filtration of nutrients into streams). They also concluded that landscape health could be defined in terms of both terrestrial and aquatic goods and services. Moreover, conditions in the landscape often link aspects of terrestrial and aquatic systems. For example, intact forests retain water and nutrients, hence reducing the off-load of nutrients to streams (Franklin 1992). Excess nutrients in streams are known to decrease the quality of habitat for stream biota (Franklin 1992). However, to date, few attempts have been made to quantitatively integrate aspects of aquatic and terrestrial health into broadscale regional assessments of landscape health.

Examining the extent and magnitude of landscape changes is paramount to assessing risks to ecological resources and their associated processes (Hunsaker et al. 1990). Until recently, assessments of broad-scale changes in landscape condition were nearly impossible. However, new data on landcover change at relatively fine scales (30-60 meters) across broad regions, along with the development of spatially distributed landscape models, now make it possible to evaluate the extent and magnitude of landscape change and the impact of observed changes on aquatic and terrestrial resources (O'Connell et al. 2000; Jones et al. 2001). For example, the North American Landscape Characterization Program (NALC) has produced an archive of Landsat Multispectral Scanner (MSS) imagery that permits construction of landcover data for the early 1970s, the mid1980s, and the early 1990s across the United States and other countries (Lunetta et al. in press). Furthermore, the Multi-Resolution Land Characteristics Consortium (MRLC) has produced landcover data (National Land Cover Database or NLCD) for the entire coterminous United States at a resolution of 30 meters for the early 1990s, and plans are underway to produce a similar early $2000 \mathrm{~s}$ database by 2005 (Vogelmann et al. 2001). Taken together, these two programs permit relatively finescale assessments of landscape change across very large areas.

Taking advantage of the NALC imagery and the MRLC landcover database and model concepts developed by O'Connell et al. (2000) for birds and by Jones et al. (2001) for nitrogen yield, we assessed patterns of landcover change and their associated impacts on landscape or land health related to bird habitats and nitrogen yield to streams across the United States mid-Atlantic region. Although land health is limited to nitrogen yield and bird habitat conditions in this study, we demonstrate a method that can be used with more comprehensive sets of values and models.

\section{METHODS}

The study was undertaken in the mid-Atlantic region of the United States (southern New York, Pennsylvania, western New Jersey, Delaware, Maryland, West Virginia, Virginia, northern North Carolina) (Figure 1). Digital landcover maps were acquired and processed to examine the spatial concordance of temporal changes in nitrogen load and temporal changes in an index of bird habitat quality. Overall, the methodology can be separated into three steps: (1) acquire and process landcover data for two time periods; (2) use the landcover data to run nitrogen load and bird habitat models for each time period; and (3) compare outputs of models across time and themes (nitrogen and bird habitat).

The temporal landcover data were from the early 1970s and early 1990s. The 1970s landcover data were created from Landsat MSS data that were acquired as part of the NALC program (Lunetta et al. in press). The NALC program distributed the MSS data at a resampled pixel size of 60 meters. The 1990s data were acquired from the MRLC program (Loveland \& Shaw 1996). An objective of the MRLC program was to map landcover for the conterminous United States (Vogelmann et al. 


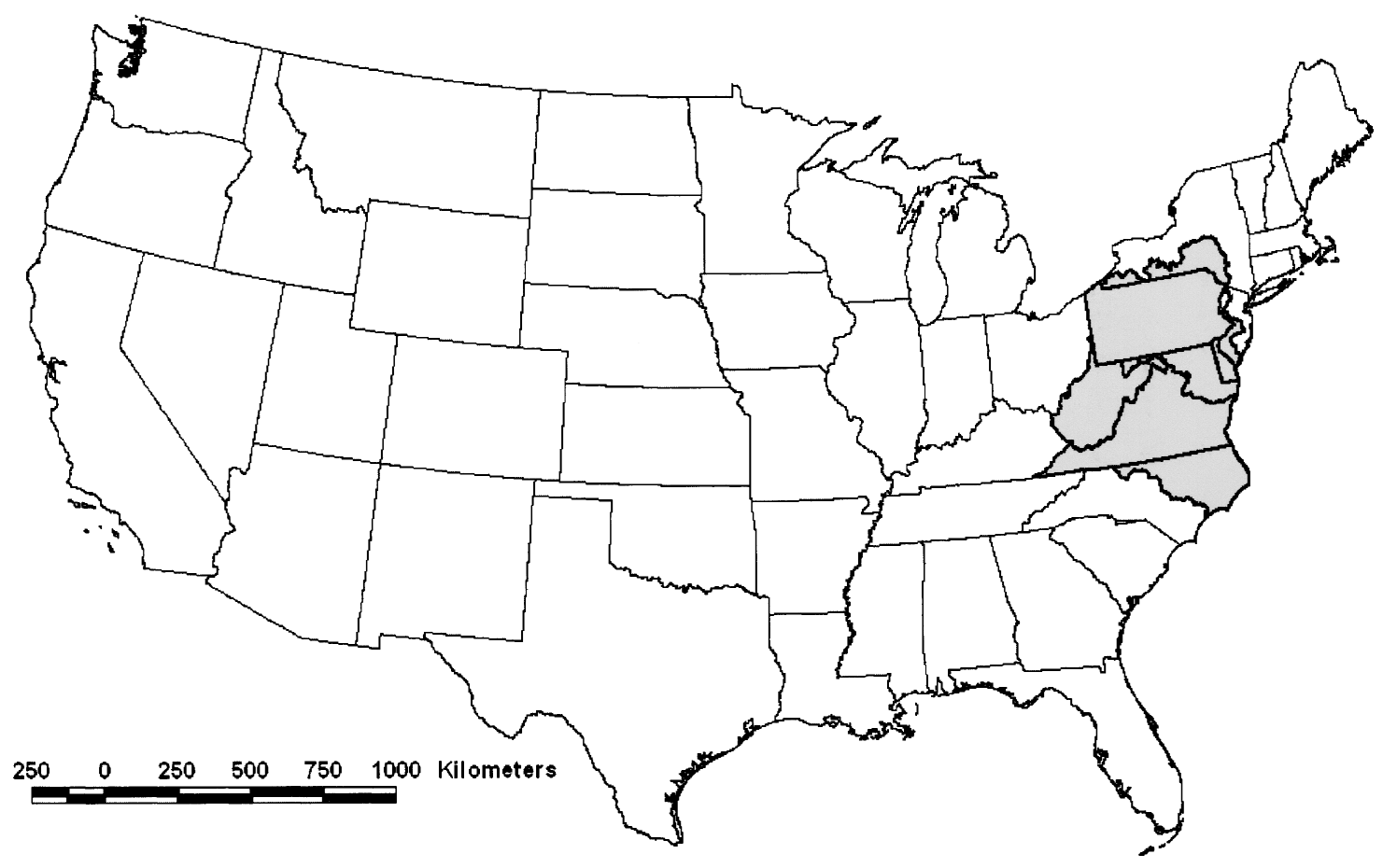

FIGURE 1. Geographic distribution of the mid-Atlantic region.

2001) using 30-meter data from the Landsat Thematic Mapper (TM).

Unlike MRLC, there were no preexisting landcover data from the NALC program for the 1970s. The NALC Landsat MSS data were classified into six landcover classes using euclidean minimum-distance-to-mean clustering and ancillary data. The primary ancillary data sets were U.S. Geological Survey Land Use Data Analysis (LUDA) landcover and National Wetlands Inventory (NWI) data. The six landcover classes were: water, forest, agriculture (herbaceous), emergent wetland, urban (developed), and bare ground (bare rock, sand, mines).

Both landcover data sets were resampled to a 120 -meter pixel in order to accommodate for the differences in native spatial resolution (30-meter Landsat TM and 60-meter NALC Landsat MSS). Also, the two data sets were calibrated so that no urban areas in the 1970 Landsat MSS landcover data were lost in the 1990 landcover data because of increasing tree density in maturing residential areas. Areas classified as urban in 1970 but not in 1990 were changed to urban in the 1990 landcover data.

The study area was tessellated into $25-\mathrm{km}^{2}$ grid cells to accommodate the nitrogen and bird habitat models and avoid per pixel calculation of changes between the two landcover maps (Townshend et al. 2001). Statistics of landcover percentages in the 1970s and 1990s were calculated for each of the $25-\mathrm{km}^{2}$ grid cells, as was nitrogen deposition.

The nitrogen load model was taken from Jones et al. (2001), which empirically estimated the mass of nitrogen output from several watersheds in the mid-Atlantic region using flow-adjusted concentrations. The Jones et al. (2001) model estimated nitrogen load as a function of riparian cover and nitrate deposition. For this study, the model was recalibrated with riparian cover removed because of the fourfold increase in spatial resolution (30- to 120 -meter pixels). The model was recalibrated using stepwise regression without inclusion of the riparian cover metric. The recalibration replaced riparian cover with agriculture (with the appropriate change in signs) and retained nitrogen deposition:

$$
\operatorname{Ln}(\mathrm{N})=
$$

$$
0.02114 \mathrm{alc}+0.00175 \mathrm{nd}-1.58487 \text {, where }
$$

alc is the proportion of watershed in agriculture, nd is nitrate deposition $(\mathrm{kg} / \mathrm{yr})$, and $\mathrm{N}$ is nitrogen yield $(\mathrm{kg} / \mathrm{ha} / \mathrm{yr})$. The R-square was 0.80 , with alc and nd explaining $57 \%$ and $24 \%$ of the variance, respectively. The nitrogen load model uti- 
lized the landcover percentages described above, and a digital surface map of nitrogen deposition (Jones et al. 2001).

The bird model was taken from O'Connell $e t$ al. (2000). The model characterizes the relationship between bird community index (BCI) scores and landscape conditions. A first-level characterization of the model stratified bird habitat into poor, moderate, and good to excellent based on the percentage of forest cover (calculated for each $25-\mathrm{km}^{2}$ grid cell). Areas with less than $41 \%$ forest cover were considered in poor condition and areas greater than $80 \%$ forest were considered in good to excellent condition. Areas between $41 \%$ and $80 \%$ were considered moderate. A second level of characterization in the model considered the type of nonforest landcover. When forest cover was less than $41 \%$ and urban was greater than $33 \%$, the site was considered poorurban. If forest was less than $41 \%$ and agriculture was greater than $50 \%$, the site was considered poor-agriculture. O'Connell et al. (2000) found that different groups of birds occupied poorurban and poor-agriculture sites.

In our implementation of the model, we found other poor areas that met neither the poorurban nor poor-agriculture criteria. These sites were mixtures of agriculture, developed, and forest, and also included large amounts of barren (mines or large clear-cuts). We characterized these areas as poor-other. Our application of the O'Connell et al. (2000) model included five classes: good to excellent, moderate, poor-urban, poor-agriculture, and poor-other.

The models were applied to each grid cell using each landcover data set to uncover temporal changes in each theme. The differences in each theme were also compared to determine the spatial concordance of changes in bird habitat and nitrogen yield.

\section{RESULTS}

\section{LANDSCAPE CHANGE}

Changes in landcover types across the mid-Atlantic region from the early 1970s to the early 1990s were relatively small. Of the six landcover classes, urban increased the most and herbaceous landcover decreased the most. Forests, water, and barren land experienced small increases, and emergent wetlands very small decreases (Table 1). However, the spatial pattern of changes in landcover varied considerably across the region, especially changes in forest, herbaceous, and urban landcover. Unfortunately, it was not possible to depict this pattern at the scale of the region, although spatial variation was evident in the maps of the model results (see below). Relatively large forest gains were seen in west-central Pennsylvania, northern West Virginia, in the headwaters of the Chesapeake Bay watershed in southern New York and Pennsylvania, and in southern Virginia. The greatest gains in herbaceous landcover were seen in the large agricultural areas in the central part of the region, on the Delmarva Peninsula, in extreme southeast Virginia along the coast, and in extreme northwest Pennsylvania and southwestern New York. Urban landcover increased in and around large urban areas of the eastern seaboard and in southern Virginia and northern

\section{TABLE 1}

Percentage of different landcover types and their changes across the mid-Atlantic region from the early 1970 s to the early 1990 s

\begin{tabular}{|c|c|c|c|c|c|c|}
\hline & Water & Forest & $\mathrm{Ag}$ & $\begin{array}{l}\text { Emergent } \\
\text { Wetlands }\end{array}$ & Urban & Barren \\
\hline $1970 \mathrm{~s}$ & 6.17 & 62.56 & 26.27 & 1.01 & 3.59 & 0.40 \\
\hline $1990 \mathrm{~s}$ & 6.65 & 62.85 & 23.76 & 0.90 & 4.92 & 0.92 \\
\hline Changes in $\%$ & & & & & & \\
\hline Composition & $+0.48 \%$ & $+0.29 \%$ & $-2.51 \%$ & $-0.11 \%$ & $+1.33 \%$ & $+0.48 \%$ \\
\hline
\end{tabular}

$\mathrm{Ag}=$ agriculture 


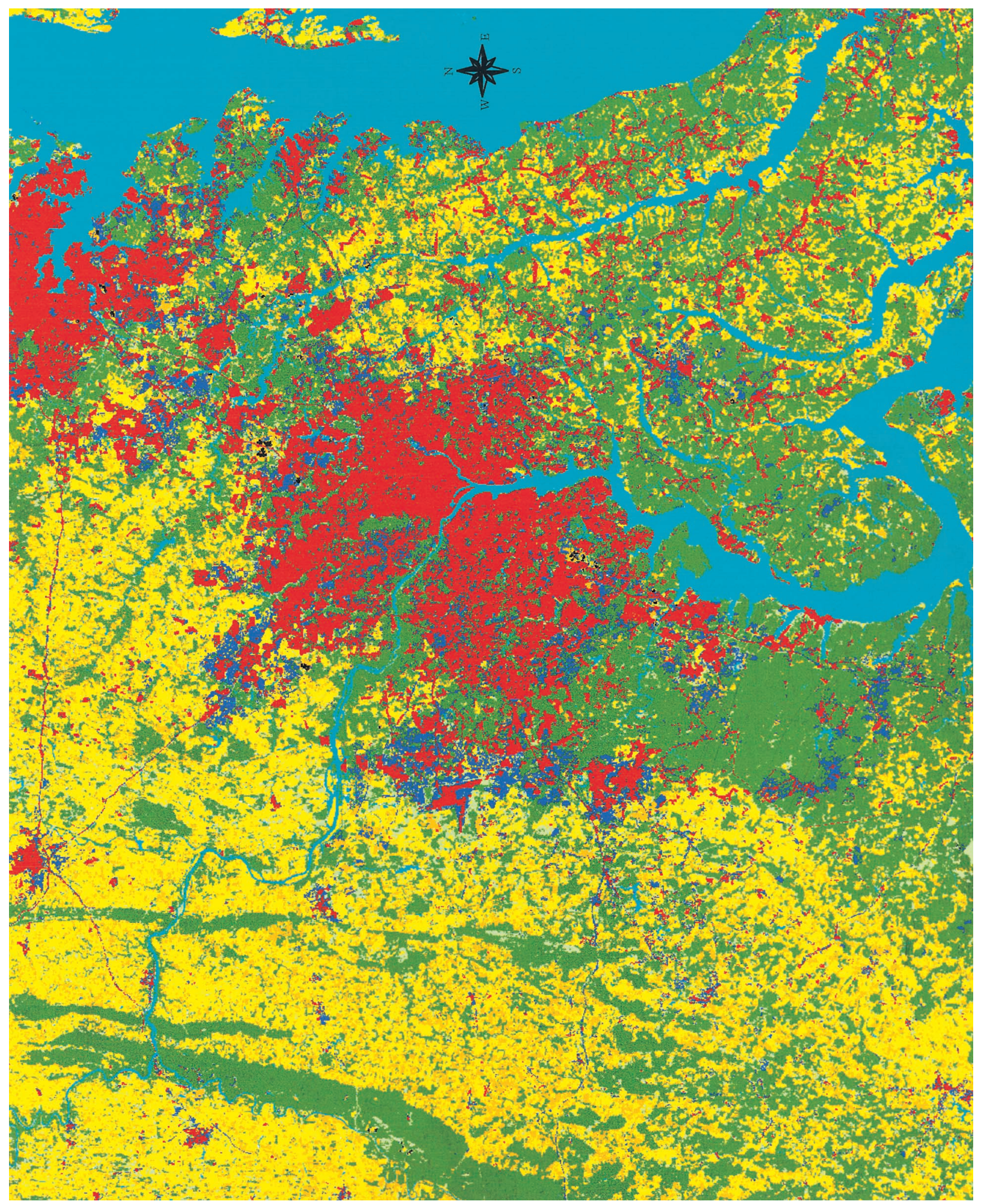

FIGURE 2. Landscape change in the Washington, D.C. area. Red color is urban (no change), dark blue is urban expansion, green is forest (no change), yellow is herbaceous/agriculture (no change), orange is herbaceous gain, light green is forest gain, aqua blue is water. The large urban patch in the middle of the image is the Washington, D.C. metropolitan area. 
North Carolina. Generally, the spread of urban growth occurred around the periphery of existing urban areas (Figure 2). Most herbaceous (agricultural) loss resulted from gains in urban and forest landcover, whereas agricultural gain was associated with losses of forest. Forest losses were associated with gains in agricultural in mixed agriculture/forest landscapes, as well as expanding urban centers, although the former was much greater. There also was forest loss and gain associated with wetland areas (for example, on the Delmarva Peninsula) and major river systems, primarily in the east-central part of the region (Table 2). These changes may reflect differences in the amount of water associated with different climatic conditions in the 1970s versus the 1990s.

\section{BIRD HABITAT CHANGES}

At the regional scale, $79.07 \%$ of the bird habitat remained in the same condition class between the early 1970 s and early 1990 s; $20.93 \%$ of the $25-\mathrm{m}^{2}$ grid cells changed. Approximately 29\% of the bird habitat in the region remained in good condition, $40 \%$ in moderate condition, and $11 \%$ in poor condition (Table 3 ). There was a $4.83 \%$ gain of poor habitat across the region and a $7.67 \%$ increase in good habitat between the early 1970s and the early 1990s. Approximately 3\% of the moderate habitat was converted to poor and $7 \%$ to good (Table 3).

Because the model was based on changes in herbaceous, forest, and urban landcover types (see Methods), the spatial pattern of bird habitat changes reflected the spatial pattern of landcover changes (Figure 3) but not entirely. This difference results from the bird habitat model; transition to poor conditions requires a loss in forests and a gain in either herbaceous or urban landcover. Additionally, a relatively small loss or gain of forest can result in a transition to another condition class-e.g., those grid cells at or near the condition-class thresholds.

It was not possible to depict the spatial pattern of all habitat transitions in a clear manner for the entire region; therefore, only the direction of change is illustrated. There were positive habitat changes in and around large forested areas in West Virginia and northern Pennsylvania, central and southern Virginia, southern New York State, and directly north of Pittsburgh, Pennsylvania. Negative habitat changes occurred in and around large urban centers, on the Delmarva Peninsula, along the eastern seaboard of North

\section{TABLE 2}

Amount and percentages of change from one landcover type to another. $1=$ water, 2 = forest, $3=$ herbaceous, $4=$ emergent wetland, $5=$ urban, $6=$ bare ground. Urban losses are not reported because the change estimates assumed no urban loss (see Methods section)

\begin{tabular}{llll}
\hline $1970 \quad 1990 \quad \mathrm{~km}^{2}$ of change & $\%$ change \\
\hline
\end{tabular}

\begin{tabular}{lccc}
1 & 2 & 423.32 & $50 \%$ \\
1 & 3 & 118.67 & $14 \%$ \\
1 & 4 & 194.26 & $23 \%$ \\
1 & 5 & 64.81 & $7 \%$ \\
1 & 6 & 56.83 & $6 \%$ \\
& Total & 857.89 & \\
2 & 1 & 1597.03 & $5 \%$ \\
2 & 3 & 27574.39 & $80 \%$ \\
2 & 4 & 415.33 & $1 \%$ \\
2 & 5 & 2588.07 & $8 \%$ \\
2 & 6 & 2130.23 & $6 \%$ \\
& Total & 34305.05 & \\
3 & 1 & 881.65 & $2 \%$ \\
3 & 2 & 33889.42 & $89 \%$ \\
3 & 4 & 161.29 & $0.40 \%$ \\
3 & 5 & 3083.04 & $8 \%$ \\
3 & 6 & 132.61 & $0.30 \%$ \\
& Total & 38148.01 & \\
4 & 1 & 427.04 & $34 \%$ \\
4 & 2 & 555.42 & $45 \%$ \\
4 & 3 & 173.15 & $14 \%$ \\
4 & 5 & 56.92 & $5 \%$ \\
4 & 6 & 27.55 & $2 \%$ \\
& Total & 1240.07 & \\
6 & 1 & 54.57 & $4 \%$ \\
6 & 2 & 794.480 & $62 \%$ \\
6 & 3 & 311.8 & $24 \%$ \\
6 & 4 & 5.25 & $0.40 \%$ \\
6 & 5 & 120.97 & $9 \%$ \\
& Total & 1287.07 & \\
\hline & & &
\end{tabular}

Carolina, and in large agricultural valleys of the Appalachian Mountains (Figure 3).

\section{NITROGEN YIELD CHANGES}

Because of the lack of a spatial coverage of nitrogen deposition for the early 1970s, it was not possible to assess how combinations of nitrogen deposition and herbaceous landcover changes affected nitrogen yield. Therefore, nitrogen change estimates are based entirely on changes in herbaceous landcover (see Methods). At the regional scale, there 
TABLE 3

Changes in the condition of bird habitats across the midAtlantic region. Numbers are changes in the proportion of conditions from one condition class to another averaged over 15,918 $25-\mathrm{km}^{2}$ cells and are expressed as percentages
Remained poor

Poor to moderate

Poor to good

Moderate to poor

Remained moderate

Moderate to good

Good to poor

Good to moderate

Remained good

No change

Total change
$11.13 \%$

$3.27 \%$

$0.04 \%$

$4.72 \%$

$40.23 \%$

$7.63 \%$

$0.11 \%$

$4.05 \%$

$28.82 \%$

$79.07 \%$

$20.93 \%$ was an average decrease in the amount of nitrogen yield to streams based on model runs for the $25-\mathrm{m}^{2}$ grid cells $(-0.35 \pm 2.80)$. Similar to changes in bird habitats, there was considerable spatial variation in nitrogen yield changes. The spatial pattern reflects landcover changes described earlier. Large spatial clusters of decreases of greater than $6.55 \mathrm{~kg} / \mathrm{ha} / \mathrm{yr}$ in nitrogen yield occurred in southern New York State, the Pocono Mountain region of eastern Pennsylvania, and western Pennsylvania north of Pittsburgh. Areas with smaller decreases in nitrogen yield were spatially concordant with areas of greater nitrogen yield loss, except for a relatively large patch of smaller decreases in south-central Virginia and extreme western Virginia. Two large clusters of relatively large nitrogen yield gain $(>6.93 \mathrm{~kg} / \mathrm{ha} / \mathrm{yr})$ occurred in the mountainous regions of northern Virginia, north-central Maryland, and south-central Pennsylvania. Relatively lower gains in nitrogen yield $(1.42-6.92 \mathrm{~kg} / \mathrm{ha} / \mathrm{yr})$ were spatially extensive across central and northwestern Pennsylvania, on the Delmarva Peninsula, in eastern North Carolina, and in the valleys of the Appalachian Mountains of Virginia (Figure 4).

\section{CONCORDANCE BETWEEN CHANGES IN NITROGEN YIELD AND BIRD HABITAT CONDITIONS}

As expected, there were some coincident spatial patterns of bird habitat and nitrogen yield changes between the early 1970s and early 1990s across the mid-Atlantic region (Figure 5). Spatial clusters of decreases in nitrogen yield and increases in bird habitat quality occurred in northern Pennsylvania and southern New York State, western Pennsylvania, the Pocono Mountains of eastern Pennsylvania, and northern West Virginia. Generally, spatially concordant patterns of improving conditions for nitrogen yield and bird habitats were nested within larger areas of declining nitrogen yield. This was also true of spatially concordant patterns of declining habitat quality and increasing nitrogen yield; declining conditions for both bird habitat quality and nitrogen yield tended to be within larger clusters of increasing nitrogen yield. Spatial clusters of declining conditions occurred on the Delmarva Peninsula, coastal areas of North Carolina and southern Virginia, large agricultural valleys in the Appalachian Mountains of Virginia, western Maryland, and south-central, central, and northwestern Pennsylvania. Spatially discordant patterns between changes in nitrogen yield and bird habitat quality were primarily a function of the distribution of bird habitat quality changes. Changes in bird habitat conditions tended to be more widespread and of a finer grain nature, particularly in areas with negative changes in bird habitat conditions. Positive changes in bird habitats tended to be on the edges of concordance patterns of improvement in bird habitat and nitrogen yield, except in the southern part of the region, where several patches of improving habitat quality were spatially discordant with improvements in nitrogen yield (Figure 5).

\section{DISCUSSION}

Evaluation of changes in landscape health requires the development of spatially distributed models that relate various aspects of landscape condition (e.g., landcover composition and pattern) to environmental endpoints (Jones et al. 2000), in as much as landscape health is defined relative to those environmental endpoints of interest to society (Sutter 1990; Rapport et al. 1998). Moreover, it is cost prohibitive to monitor changes in environmental endpoints at relatively fine scales across large regions (Jones et al. 2000; Reckhow 2001). Recent development of spatially distributed models made it possible to demonstrate how landscape changes across the mid-Atlantic region from the early 1970s to the early 1990s affected bird habitat quality and nitrogen yield to streams. Moreover, 


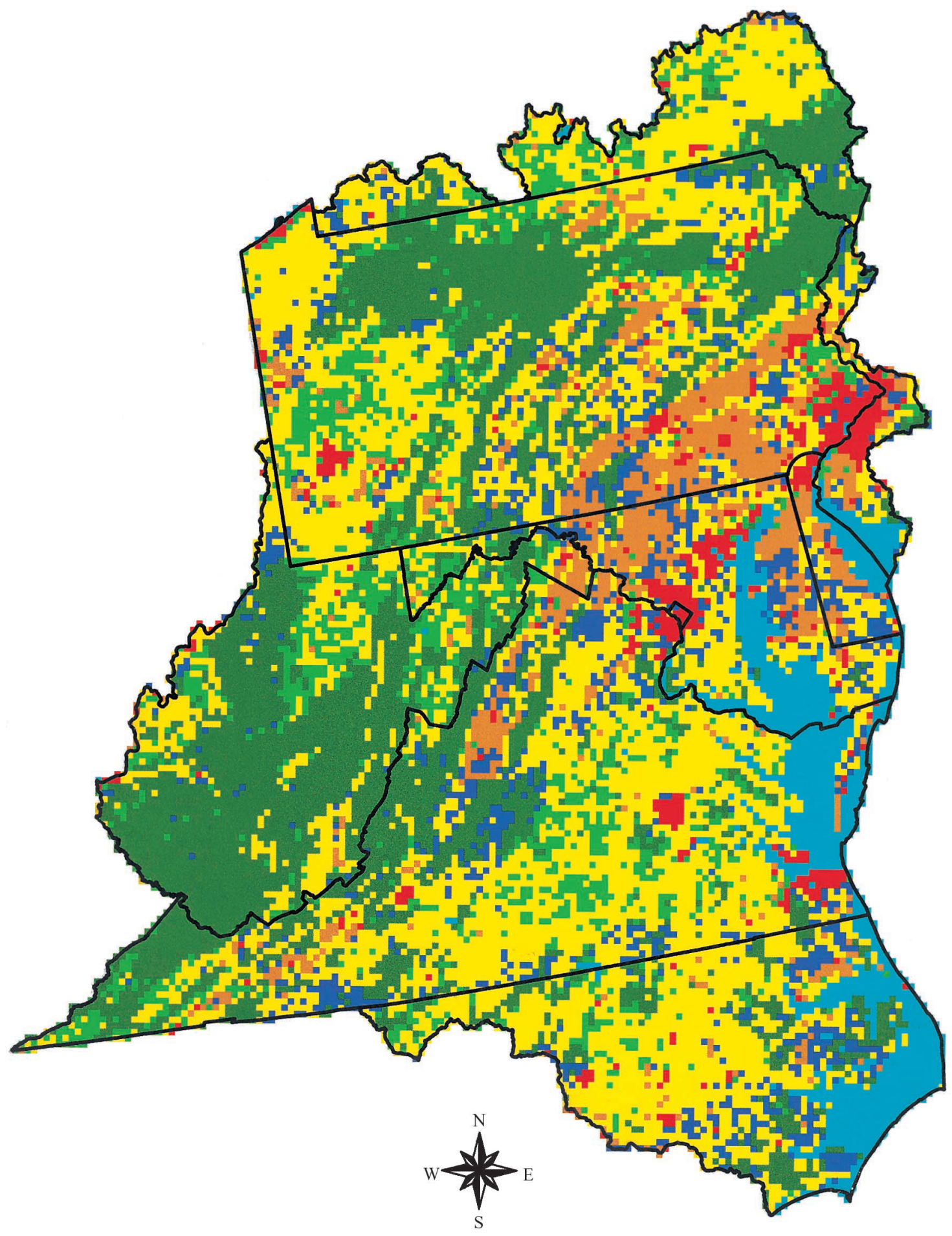

FIGURE 3. Spatial pattern of bird habitat condition changes across the mid-Atlantic region. Changes are depicted by $25-\mathrm{km}^{2}$ grid cells. Dark green = good habitat condition (no change), light green = a positive change in habitat condition, yellow = moderate habitat conditions (no change), dark blue $=$ a negative change in habitat conditions, red = poor habitat conditions (urban, no change), brown = poor habitat conditions (agriculture, no change), and aqua blue = water (no change). 


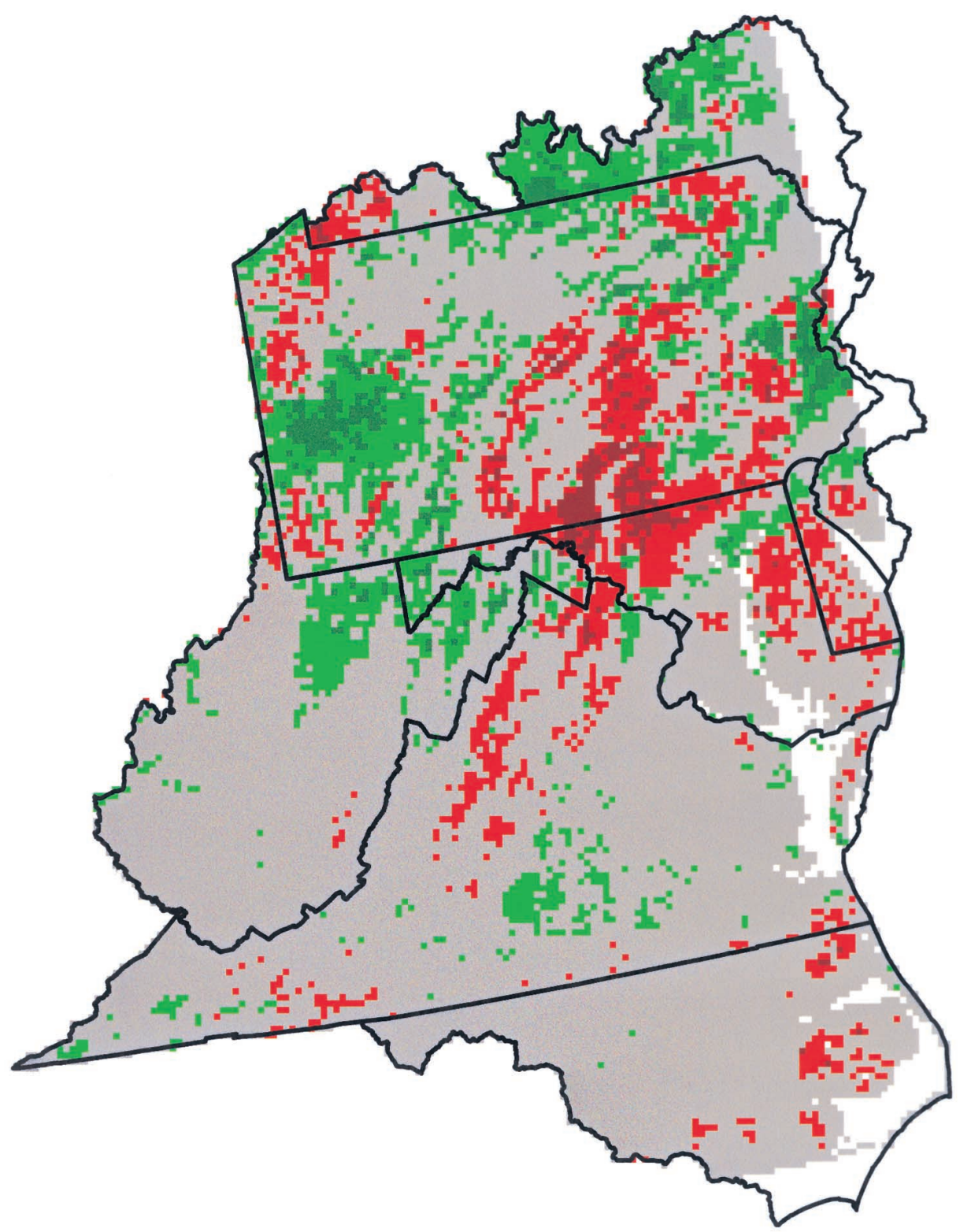

Nitrogen Yield Changes (kg/ha/yr)

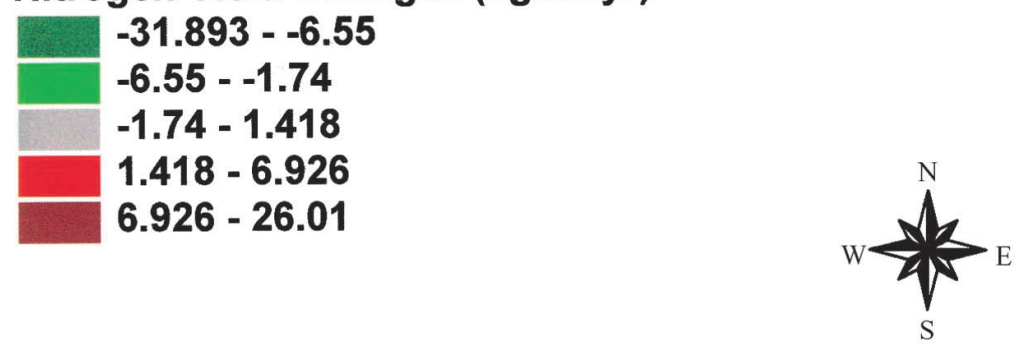

FIGURE 4. Spatial pattern of nitrogen yield changes across the mid-Atlantic region. Changes are depicted by $25-\mathrm{km}^{2}$ grid cells. Changes are in kg/ha/yr. 


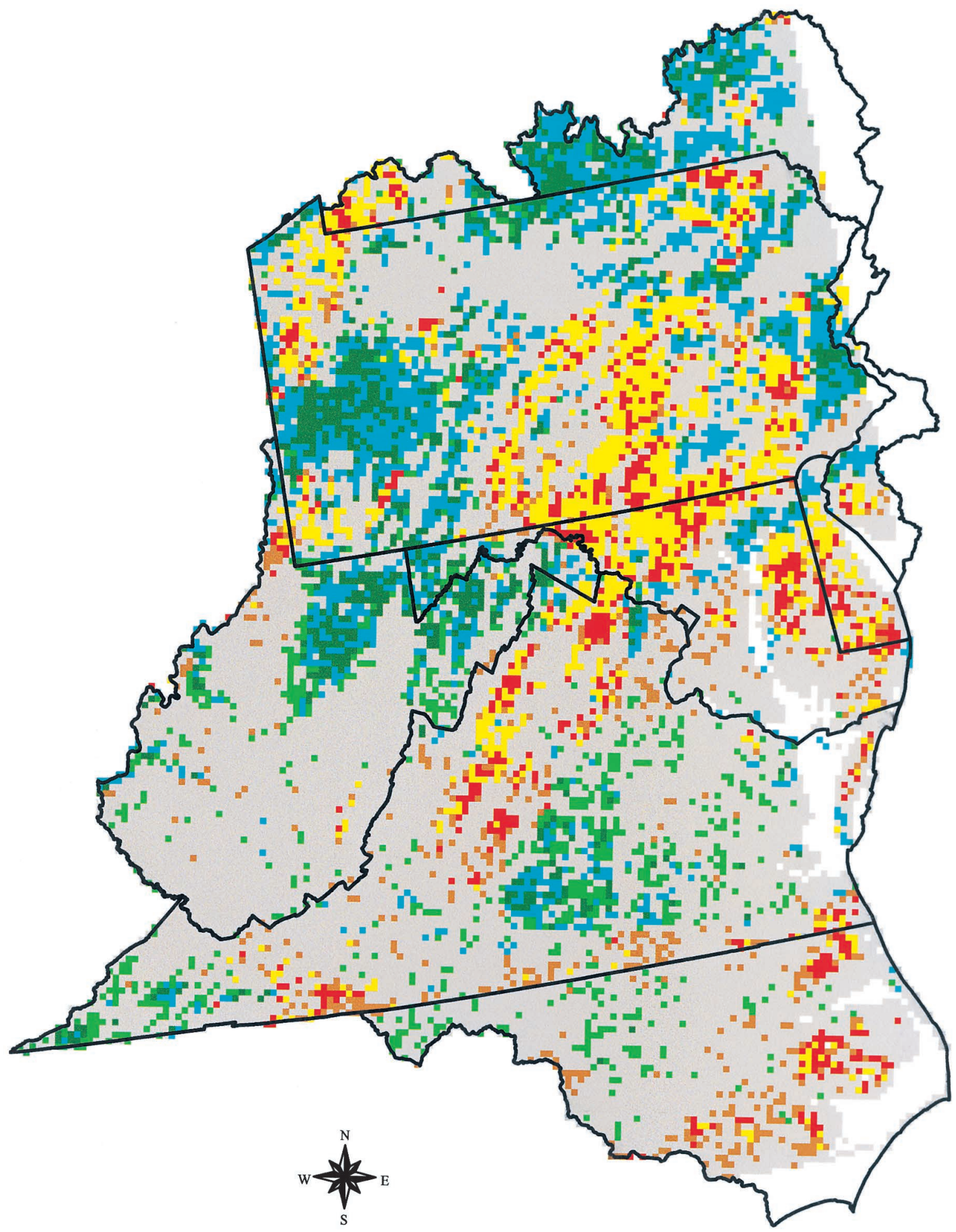

FIGURE 5. Spatial concordance in the direction of change of bird habitat condition and nitrogen yield. Concordance in the direction of change is depicted by $25-\mathrm{km}^{2}$ grid cells. Red = condition declines for habitat and nitrogen yield, yellow $=$ condition decline for nitrogen yield and no change for habitat, brown = condition decline for habitat and no change for nitrogen yield, blue = improved conditions for nitrogen yield and no change for habitat, light green $=$ improved conditions for habitat and no change for nitrogen yield, and dark green = improved conditions for habitat and nitrogen yield. 
because both models were implemented in a Geographic Information System (GIS), it was possible to compare spatial concordance between these two environmental endpoints in this study.

At the scale of the mid-Atlantic region, the amount of change in bird habitat condition and nitrogen yield was relatively small. However, we demonstrated considerable spatial variation in landscape change as it relates to bird habitats and nitrogen yield. Areas that experienced declines in bird habitat and increases in nitrogen yield (worsening conditions) had common themes in landscape change. Based on the two models, these areas had agricultural and urban landcover gains at the expense of forests. Declines in condition tended to be in spatial clusters associated with urbanization and agricultural expansion in areas with large blocks of agriculture in the early 1970s. Although not quantified in this study, urban expansion tended to occur around urban areas that existed in the early 1970s. The observed pattern of urbanization is consistent with patterns predicted from transportation theory (Giuliano 1999). Wickham et al. (2000) showed a pattern of increasing forest fragmentation with decreasing distances from urban areas in the mid-Atlantic region. They concluded that this relationship existed because land value decreases as one moves away from urban centers. Similarly, Vogelmann (1995) showed an association between forest loss and urbanization in New England. Conversely, forest gain was almost always at the expense of herbaceous or agricultural landcover. In areas that were predominately forest, loss of herbaceous landcover may have been associated with transitions of forest from early, herbaceous successional stages to tree growth.

Urban sprawl and associated land uses have been cited as primary drivers of declines in environmental conditions in the United States (Flather et al. 1998) and other areas of the world (Houghton 1994). Although some areas of the mid-Atlantic region exhibited high amounts of urbanization between the 1970s and 1990s, a relatively small amount of total area in the region was converted to urban.

We were somewhat surprised by the number and location of areas that exhibited gains in forests, and hence, improved conditions for birds and nitrogen loadings. Some of these areas represented the recovery of forests from bark beetle outbreaks, including forests in the upper elevations of the Blue Ridge Mountains, and some from reestablishment of forests in agricultural ar- eas. However, some of the gain in forests in agricultural areas may represent error in the landscape data (see discussion below). Finally, we were surprised with the extent and magnitude of bird habitat loss and increased nitrogen loading potential on the Delmarva Peninsula and coastal areas of southern Virginia and North Carolina. Most of the change on the Delmarva represented increases in agriculture, whereas southern Virginia and North Carolina were more of a mix of increases in urban and agriculture.

Differences in the grain size and patchiness of changes in bird habitat quality and nitrogen yield likely resulted from differences between the two spatially distributed models. The bird model was a rule-based model resulting in categorical scores for each of the grid cells (poor, moderate, and good, O'Connell et al. 2000), whereas the nitrogen yield model was a statistical model resulting in a continuous variable of predicted nitrogen yield (Jones $e t$ al. 2001). A bird model that creates a continuous variable of habitat quality would permit a more direct comparison of changes in the spatial pattern of bird habitat quality and nitrogen yield.

Because of the nature and quality of the 1970s Landsat MSS data, it was difficult to decipher whether transitions from forest to herbaceous and vice versa were losses or gains in agriculture, or changes in successional patterns in forests. Correctly identifying these transitions impacts the results of the bird habitat quality and nitrogen yield model. Early successional forests likely lose less nitrogen and provide better bird habitat than agricultural fields because the latter has bare soil for at least six months. Knowing something about the predominate landcover in an area may improve our ability to tease apart these two types of herbaceous classes and improve model results. Wickham and Norton (1994) developed a landscape classification, Landscape Pattern Types (LPTs), based on the proportions of landcover in an area. Such an approach may assist us in evaluating the kinds of transitions one might expect in a given landscape. In a similar way, we improved estimates of urban or developed areas in the 1990s by making the assumption that urban areas could not be lost between the 1970s and 1990s. Initially, we found that urban or developed areas were lost within the boundaries of cities and along major highways. By evaluating the transition type (e.g., urban to forest) and location (e.g., within an urban area), we concluded that the loss of urban landcover was due to maturing of individual trees. Therefore, we assumed that loss of 
urban was very unlikely and reclassified those urban pixels that had changed back to urban. Understanding transition probabilities as well as the landscape setting may improve landcover change estimates substantially and the spatially distributed models that depend on them.

One of the biggest issues confronting those doing regional environmental assessments is how to best represent and depict the surface of a region. Probability samples consisting of unbiased measurements of ecological indicators are one way to estimate ecological conditions over broad areas (Messer et al. 1991). However, decision makers and environmental managers within a region invariably want to know the condition of the area that they manage and how their area compares with other areas. Therefore, some type of spatial extrapolation is needed to estimate conditions across the surface of a region. We believe that spatially distributed models similar to the two used in this study are one way to extrapolate conditions to a continuous surface. And when these models are quantitatively associated with landscape metrics generated from continuous spatial data, spatial concordance between multiple environmental endpoints can be evaluated, leading to a comprehensive assessment of landscape health.

It also is important to decide how to depict the spatial variability of model results given that potential users of such results need data at a range of spatial scales. Several regional scale reports have used 8-digit Hydrological Unit Code watersheds to depict and report environmental conditions, including indicator summaries based on relatively fine-scale landscape data (Jones et al. 1997). At the scale of a large region, this representation of spatial variation may be appropriate, but to be useful for state and county organizations, finer-scale spatial representation may be necessary. The use of $25-\mathrm{km}^{2}$ grid cells in this study demonstrated that spatial variation can be depicted at a scale useful for regional as well as finer-scale assessments. Grid-cell techniques also have proven useful for habitat evaluations at local scales (e.g., Cross \& Petersen 2001). However, the models used to evaluate conditions must be related to land features and the spatial realm upon which key processes operate. In our study, both models were related to land features where a grid cell concept would apply. There are some cases, however, where a grid cell design would not apply. For example, for some water-related processes and endpoints, a watershed delineation may be more appropriate.
Both the bird and nitrogen models used in this assessment were first approximations of the spatial pattern of change in conditions across the mid-Atlantic region. Other factors may contribute to the quality of bird habitat and nitrogen loadings at finer scales (e.g., an individual forest stand or stream), and hence, make it hard to predict the number of bird species or amount of nitrogen loadings to streams from models used in this study. For example, excellent and good bird habitat quality in the mid-Atlantic region can only be discriminated by estimating differences in forest stand characteristics (O'Connell et al. 2000). Similarly, point sources of nitrogen (e.g., pig farms and other facilities) can influence the amount of nitrogen in individual streams (Behrendt et al. 1999) and these kinds of sources of nitrogen go undetected by Landsat imagery.

Qualitatively, it is possible to describe potential implications of observed landscape changes in the mid-Atlantic region on other aspects of landscape health. Areas that lost forests were more likely to have lost interior forest species and have experienced increases in run-off and flood-related disturbances that affect stream biological conditions than areas that maintained or gained forests. Similarly, areas that lost forests are more likely to have experienced increases in forest edges than areas that maintained or gained forests. An increase in the number of edges, especially where roads are involved, can increase the spread of certain exotic species (Rosenberg et al. 1991; Askins 2000). Jones et al. (1997) and Wickham et al. (1999) provide qualitative summaries and methods relating landscape conditions to a variety of ecological endpoints across the mid-Atlantic region. However, the development of additional models linking landscape conditions to other ecological endpoints will expand the interpretative power of landscape change assessments and permit a more comprehensive assessment of ecosystem health and ecological risk. For example, it may be possible to link exotic species, forest productivity, terrestrial species diversity, and other ecological endpoints to some of the landscape metrics used in this assessment, along with additional spatial measures, including those related to soil texture, forest and urban edge, road networks, and basic biophysical attributes, such as climate and geology.

The results of this assessment should help environmental managers in the mid-Atlantic region target geographic areas where restoration, management, or changes in policies are needed to 
slow, stop, or reverse declining environmental trends. The maps of changing conditions might also be used to identify areas where more detailed studies are needed to identify ecological conditions and risks.

Spatially distributed models similar to those used in this study also can be used to evaluate the consequences of alternative landscape futures on environmental endpoints. In this case, the models evaluate changes between current conditions and alternative landscape conditions projected by socioeconomic models, biophysical models, or those developed by land use planners to identify options with the least environmental impact (White et al. 1999). When applied over large areas, this approach might provide the most effective way to evaluate cumulative risk and ways to reduce future risks to ecological resources.

\section{ACKNOWLEDGMENTS}

We thank Timothy O'Connell and Robert Brooks (Pennsylvania State University) and Laura Jackson (U.S. Environmental Protection Agency (EPA)) for assistance in implementing the bird model used in this study, and four anonymous reviewers for their thoughtful comments on the manuscript. We also thank the EPA Global Climate Change Program for financial assistance in acquiring and interpreting historical satellite imagery.

The research for this paper has been funded by the U.S. EPA, through its Office of Research and Development. The paper has been formally reviewed by the Agency, and approved for publication. Mention of trade names does not infer endorsement or recommendation for use.

\section{REFERENCES}

Askins, R.A. (2000) Restoring North America's Birds: Lessons from Landscape Ecology. Yale University Press, New Haven, CT.

Behrendt, H., Ley, M., Korol, R., Stronska-Kedzia, M., Pagenkopf, W. (1999) Point and diffuse nutrient emissions and transports in the Odra Basin and its main tributaries. Acta Hydrobiologia et Hydrochimica 27, 274-281.

Cross, C.L. \& Petersen, C.E. (2001) Modeling snake microhabitat from radiotelemetry studies using polytomous logistic regression. Journal of Herpetology $\mathbf{3 5}$, 590-597.

Franklin, J. F. (1992) Scientific basis for new perspectives in forests and streams. In: Naiman, R.J. (ed)
Watershed Management. pp. 25-72. Springer-Verlag, New York.

Flather, C.H., Knowles, M.S., Kendall, I.A. (1998) Threatened and endangered species geography: Characteristics of hot spots in the conterminous United States. BioScience 48, 365-376.

Giuliano, G. (1999) Land use policy and transportation: Why we don't get there from here. Transportation Research Circular 495, 179-198.

Groom, M.J. \& Schumaker, N. (1993) Evaluating landscape change: Patterns of worldwide deforestation and local fragmentation. In: Kareiva, P.M, Kingsolver, J.G., Huey, R.B. (eds) Biotic Interactions and Global Change. pp. 24-44. Sinauer, Sunderland, MA.

Houghton, R.A. (1994) The worldwide extent of landuse change. BioScience 4, 305-313.

Hunsaker, C.T., Graham, R.L., Suter, G.W., II, O’Neill, R.V., Barthouse, L.W., Gardner, R.H. (1990) Assessing ecological risk on a regional scale. Environmental Management 14, 325-332.

Imhoff, M.L. (1994) Mapping human impacts on the global biosphere. Bioscience 44, 598.

Jones, K.B., Heggem, D.T, Wade, T.G., Neale, A.C., Ebert, D.W., Nash, M.S., Mehaffey, M.H., Hermann, K.A., Selle, A.R., Augustine, S., Goodman, I.A., Pedersen, J., Bolgrien, D., Viger, J.M., Chiang, D., Lin, C.J., Zhong, Y., Baker, J., Van Remortel, R.D. (2000) Assessing landscape conditions relative to water resources in the western United States: A strategic approach. Environmental Monitoring and Assessment 64, 227-245.

Jones, K.B., Neale, A.C., Nash, M.S., Van Remotel, R.D., Wickham, J.D., Riitters, K.H., O’Neill, R.V. (2001) Predicting nutrient and sediment loadings to streams from landscape metrics: A multiple watershed study from the United States mid-Atlantic region. Landscape Ecology 16, 301-312.

Jones, K.B., Riitters, K.H., Wickham, J.D., Tankersley, R.D., O’Neill, R.V., Chaloud, D.J, Smith, E.R., Neale, A.C. (1997) An Ecological Assessment of the United States MidAtlantic Region: A Landscape Atlas. EPA/600/R-97/130. Environmental Protection Agency, Washington, D.C.

Kattan, G. H., Alvarez-Lopez, H., Giraldo, M. (1994) Forest fragmentation and bird extinctions: San Antonio eighty years later. Conservation Biology 8, 138-46.

Knick, S.T. \& Rotenberry, J.T. (1995) Landscape characteristics of fragmented shrubsteppe habitats and breeding passerine birds. Conservation Biology 9, 1059-1071.

Koopowitz, H., Thornhill, A.D., Andersen, M. (1994) A general stochastic model for the prediction of biodiversity losses based on habitat conversion. Conservation Biology 8, 425-38.

Loveland, T.R. \& Shaw, D.M. (1996) Multi-resolution land characterization-building collaborative partnerships. In: Scott, J.M., Tear, T.H., Davis, F.W. (eds) GAP Analysis-A Landscape Approach to Biodiversity Planning. pp. 79-85. American Society for Photogrammetry and Remote Sensing, Bethesda, MD. 
Lubchenco, J., Olson, A.M., Brubaker, L.B., Carpenter, S.R., Holland, M.M., Hubbell, S.P., Levin, S.A., McMahon, J.A., Matson, P.A., Melillo, J.M., Mooney, H.A., Peterson, C.H., Pulliam, H.R., Real, L.A., Regal, P.J., Risser, P.G. (1991) The sustainable biosphere initiative: an ecological research agenda. Ecology 72, 371-412.

Lunetta, R.S., Alvarez, R., Edmonds, C.M., Lyon, J.G., Elvidge, C.G, Bonifaz, C.R., García, C. (In press) NALC/Mexico land-cover mapping results: implications for assessing landscape condition. International Journal of Remote Sensing.

Messer, J.J., Linthurst, R.A., Overton, W.S. (1991) An EPA program for monitoring ecological status and trends. Environmental Management 17, 67-78.

Noss, R.F. \& Cooperrider, A.Y. (1994) Saving Nature's Legacy: Protecting and Restoring Biodiversity. Island Press, Washington, D.C.

Noss, R.F., LaRoe, E.T., Scott, J.M. (1995) Endangered Ecosystems of the United States: A Preliminary Assessment of Loss and Degradation. U.S. National Biological Survey Report 28. U.S. National Biological Survey, Washington, D.C.

O’Connell, T.J., Jackson, L.E., Brooks, R.P. (2000) Bird guilds as indicators of ecological condition in the central Appalachians. Ecological Applications 10, 1706-1721.

Ojima, D.S., Galvin, K.A., Turner, B.L, II. (1994) The global impact of land-use change. BioScience 44, 300-304.

Peterjohn, W.T. \& Correll, D.L. (1984) Nutrient dynamics in an agricultural watershed: Observations on the role of a riparian forest. Ecology 65, 1466-1475.

Rapport, D.J., Caudet, C., Karr, J.R., Baron, J.S., Bohlen, C., Jackson, W., Jones, B., Naiman, R.J., Norton, B., Pollock, M.M. (1998) Evaluating landscape health: Integrating societal goals and biophysical process. Environmental Management 53, 1-15.

Reckhow, K.H. (2001) Assessing the TMDL approach to water quality management. Committee to Assess the Scientific Basis of the Total Maximum Daily Load Approach to Water Pollution Reduction. National Research Council, Washington, D.C.

Rosenberg, K.V., Omart, R.D., Hunter, W.C., Anderson, B.W. (1991) Birds of the Lower Colorado River Valley. University of Arizona Press, Tucson, AZ.

Saunders, D.A., Hobbs, R.J., Margules, C.R. (1991) Biological consequences of ecosystem fragmentation: A review. Conservation Biology 5, 18-32.

Schlesinger, W.H., Reynolds, J.F., Cunningham, G.L., Huenneke, L.F, Jarrell, W.M., Virginia, R.A., Whitford, W.G. (1990) Biological feedbacks in global desertification. Science 247, 1043-1048.

Short, J. \& Turner, B. (1994) A test of the vegetation mosaic hypothesis: A hypothesis to explain the de- cline and extinction of Australian mammals. Conservation Biology 8, 439-449.

Sutter, G.W., Jr. (1990) Endpoints of regional ecological risk assessments. Environmental Management 14, 9-23.

Townshend, J.R.G., Huang, C., Kalluri, S.N.V., Defries, R.S., Liang, S., Yang, K. (2001) Beware of per-pixel characterization of land cover. International Journal of Remote Sensing 21, 839-843.

Turner, M.G. (1989) Landscape ecology: The effect of pattern on process. Annual Reviews of Ecological Systems 20, 171-197.

Turner, B.L., II, Clark, W.C., Kates, R.W., Richards, J.F., Mathews, J.T., Meyers, W.B. (eds) (1990) The Earth as Transformed by Human Action. Cambridge University Press, Cambridge, UK.

Turner, S. J., O’Neill, R.V., Conley, W., Conley, M.R., Humphries, H.C. (1991) Pattern and scale: Statistics for landscape ecology. In: Turner, M.G. \& Gardner, R.H. (eds) Quantitative Methods in Landscape Ecology. pp. 17-49. Springer-Verlag, New York.

United Nations Environmental Programme (UNEP) (1992) World Atlas of Desertification. Edward Arnold, London.

Verboom, J., Schotman, A., Opdam, P., Metz, J.A.J. (1991) European nuthatch metapopulations in a fragmented agricultural landscape. Oikos 61, 149-156.

Vogelmann, J.E. (1995) Assessment of forest fragmentation in southern New England using remote sensing and geographic information systems technology. Conservation Biology 9, 439-449.

Vogelmann, J.E., Howard, S.M., Yang, L., Larson, C.R., Wylie, B.K., Van Driel, N. (2001) Completion of the 1990s National Land Cover data set for the conterminous United States from Landsat Thematic Mapper data and ancillary data sources. Photogrammetric Engineering and Remote Sensing 67, 650-662.

White, D., Preston, E.M., Freemark, K.E., Kiester, A.R. (1999) A hierarchical framework for conserving biodiversity. In: Klopatek, J.M. \& Gardner, R.H. (eds) Landscape Ecological Analysis: Issues and Applications. pp. 127-153. Springer-Verlag, New York.

Wickham, J.D. \& Norton, D. (1994) Mapping and analyzing landscape patterns. Landscape Ecology 9, 7-23.

Wickham, J.D., Jones, K.B., Riitters, K.H., O’Neill, R.V., Tankersley, R.D., Smith, E.R., Neale, A.C., Chaloud, D.J. (1999) An integrated environmental assessment of the US mid-Atlantic region. Environmental Management 24, 553-560.

Wickham, J.D., O’Neill, R.V., Jones, K.B. (2000) Forest fragmentation as an economic indicator. Landscape Ecology 15, 171-179.

Woodley, S.J., Kay, J., Francis, G. (1993) Ecological Integrity and the Management of Ecosystems. St Lucie Press, Ottawa, Canada. 